\title{
The Soluble Cytochrome Oxidase of Nitrosomonas europaea
}

\author{
By DAVID J. MILLER AND PAUL M. WOOD* \\ Department of Biochemistry, University of Bristol Medical School, University Walk, \\ Bristol BS8 ITD, U.K.
}

(Received 25 October 1982)

\begin{abstract}
The soluble cytochrome oxidase of Nitrosomonas europaea has been highly purified and shown to be a copper protein devoid of haem, not a cytochrome $o$ as was previously assumed. The native molecular weight was 120000 and the subunit molecular weight 35000 . Soluble cytochrome oxidase activity co-purified with nitrite reductase activity; both activities were almost certainly associated with the same protein. The possible physiological role of the nitrite reductase activity is discussed.
\end{abstract}

\section{INTRODUCTION}

Nitrosomonas europaea contains both soluble and membrane-bound cytochrome $c$ oxidase activities (Rees \& Nason, 1965; Rees, 1968; Hooper et al., 1972; Erickson et al., 1972). The membrane oxidase is an a-type cytochrome (Erickson et al., 1972); it has been termed cytochrome $a_{1}$ but, as with certain other bacterial cytochromes $a$, the $\alpha$-band maximum at $598 \mathrm{~nm}$ lies between conventional definitions of $a_{1}$ and $a a_{3}$ (Ingledew, 1978). The soluble cytochrome $c$ oxidase was first described by Rees \& Nason (1965) who also reported the presence of a soluble cytochrome $o$. The cytochrome $o$ was identified as such on the basis of CO-difference spectra, and was assumed to be responsible for the soluble oxidase activity. The soluble oxidase seems much less specific than the membrane oxidase; Hooper et al. (1972) found that, while $80 \%$ of the total cytochrome $c$ oxidase activity was membrane-bound, activity with artificial donors such as $p$-phenylene diamine and hydroquinone was almost exclusively soluble. A partial purification was described by Erickson \& Hooper (1968); using hydroquinone as the donor, they achieved only a partial separation from hydroxylamine oxidase (EC 1.7.3.4). Rees (1968) showed that cytochrome $c$ oxidase and hydroxylamine oxidase could be separated on Sephadex G-200 or on sucrose density gradients. He established a molecular weight of 128000 by the latter method but made no spectroscopic measurements. Nothing further has been published; several reviews have referred to the soluble cytochrome $o$ without comment, despite the fact that other cytochromes $o$ are almost exclusively membrane-bound.

Hooper (1968) partially purified nitrite reductase, assayed with hydroxylamine or NADH plus pyocyanin as donor, and commented on its apparent association with soluble oxidase activity. His product contained haem but the inhibition pattern led him to draw analogies with the copper-type nitrite reductase of Pseudomonas denitrificans [since renamed Alcaligenes sp. (Iwasaki et al., 1975)]. Ritchie \& Nicholas (1974) purified nitrite reductase further, without testing for oxidase activity. Separation from hydroxylamine oxidase was difficult but was achieved in very low yield. Their findings with inhibitors were similar to Hooper (1968). The product was essentially free from haem and had a small absorption maximum near $590 \mathrm{~nm}$, similar to the $P$. denitrificans copper-containing nitrite reductase (Iwasaki \& Matsubara, 1972).

Abbreviations: DAD, 2,3,5,6-tetramethyl-p-phenylenediamine; DCPIP, 2,6-dichloro-indophenol; DEDTC, diethyldithiocarbamic acid; PMS, phenazine methosulphate ( $N$-methyldibenzopyrazine methylsulphate). 
In the last few years, this nitrite reductase system has acquired environmental interest, since nitrifying bacteria such as $N$. europaea are believed to constitute the largest global source of nitrous oxide (Lipschultz et al., 1981), one of the agents implicated in the destruction of the ozone layer of the stratosphere.

\section{METHODS}

Organism and culture methods. A culture of Nitrosomonas europaea ATCC 19178 was kindly supplied by Dr N. Walker (Rothamsted Experimental Station, Herts., U.K.). The growth medium and cell culture methods were as described in Miller \& Wood (1982).

Assay methods. Cytochrome $c$ oxidase activity was measured spectroscopically by following the oxidation of reduced cytochrome $c$ at 550 to $552 \mathrm{~nm}$. Assay cuvettes contained $20 \mu \mathrm{M}$-reduced cytochrome $c$ in $50 \mathrm{mM}$-sodium phosphate buffer, $\mathrm{pH} 7.5$. The reaction was initiated by addition of the protein solution. Nitrosomonas europaea cytochrome $c 552$ was purified as previously described (Miller \& Wood, 1982). Both horse heart and N. europaea cytochromes $c$ were reduced with an excess of ascorbate in $50 \mathrm{mM}$-sodium phosphate buffer, $\mathrm{pH} 7.5$, and then separated from excess reductant by gel filtration on Sephadex G-25.

$p$-Phenylene diamine oxidase activity was assayed as described in Rees (1968) and Hooper et al. (1972), except that the buffer used was sodium phosphate (50 mM, $\mathrm{pH} 7.5$ ).

Nitrite reductase activity was assayed as described in Ritchie \& Nicholas (1974), estimating the residual nitrite by a modified Griess-Ilosvay method after incubation of enzyme solutions under $\mathrm{O}_{2}$-free $\mathrm{N}_{2}$ with $3 \mu$ mol NADH, $0.1 \mu \mathrm{mol}$ PMS and $2 \mu \mathrm{mol}$ sodium nitrite in $0.25 \mathrm{M}$-potassium phosphate buffer, $\mathrm{pH} 6.0$ for 3-10 min (total assay volume $=2 \mathrm{ml}$ ).

Protein was determined by the method of Mejbaum-Katzenellenbogen (1955), or (in column fractions only) the method of Warburg \& Christian (1941). In both cases, the protein standard was bovine serum albumin (Fraction $\mathrm{V}$, Sigma). Copper was determined in acidified preparations on a Varian Techtron AA6 atomic absorption spectrophotometer fitted with a Varian CRA-90 carbon rod atomizer. Haem was assayed as the pyridine haemochrome by standard methods.

Purification of the soluble cytochrome oxidase. A four-stage purification was developed (Table 1). Approximately $13 \mathrm{~g}$ frozen cell pellets was frozen and thawed three times (using solid $\mathrm{CO}_{2}$ and running cold water) in $10 \mathrm{~mm}$ $\mathrm{Tris} / \mathrm{HCl}, \mathrm{pH} \mathrm{8.0,} \mathrm{with} \mathrm{addition} \mathrm{of} \mathrm{a} \mathrm{few} \mathrm{crystals} \mathrm{of} \mathrm{DNAase} \mathrm{prior} \mathrm{to} \mathrm{the} \mathrm{final} \mathrm{freeze-thaw} \mathrm{cycle.} \mathrm{The} \mathrm{DNAase-}$ treated material was centrifuged at $20000 \mathrm{~g}$ for $20 \mathrm{~min}$ at $4{ }^{\circ} \mathrm{C}$; the clear red supernatant was then carefully decanted and subjected to ammonium sulphate fractionation. The fraction precipitating between 75 and $90 \%$ saturation was redissolved in $5 \mathrm{ml}$ of the $\mathrm{Tris} / \mathrm{HCl}$ buffer and desalted simultaneously with fractionation on a large column of Sephacryl S-200 $(4.5 \times 45 \mathrm{~cm})$. At this stage, the terminal oxidase was still heavily contaminated with cytochromes, mostly hydroxylamine oxidase. The peak fractions from the S-200 column were applied directly to a short column of DEAE-cellulose (DE-52) in the same buffer (column dimensions $1.5 \times 11.5 \mathrm{~cm}$ ), the column washed with $33 \mathrm{ml} 10 \mathrm{mM}-\mathrm{Tris} / \mathrm{HCl}, \mathrm{pH} 8.0$, and then eluted with a linear gradient $(0-0.5 \mathrm{M})$ of $\mathrm{NaCl}$ in starting buffer (gradient volume $400 \mathrm{ml}$ ). Spectra of the fractions containing maximal oxidase activity revealed a degree of contamination by hydroxylamine oxidase. Peak fractions from the first DE-52 column were dialysed overnight against 11 of the Tris/ $\mathrm{HCl}$ buffer containing $20 \mu \mathrm{M}-\mathrm{CuSO}_{4}$ at $4{ }^{\circ} \mathrm{C}$ (previous experience had shown that significant loss of activity occurred if copper was omitted from the dialysis buffer). The activity of the dialysate was checked, and it was then applied directly to a small $(1.5 \times 4.5 \mathrm{~cm})$ column of DE-52, washed with $66 \mathrm{ml}$ of starting buffer, and then eluted with a $400 \mathrm{ml}$ linear gradient of 0 to $0.25 \mathrm{M}-\mathrm{NaCl}$ in starting buffer. Oxidase activity coincided with the major protein peak eluting with about $0 \cdot 2 \mathrm{M}-\mathrm{NaCl}$.

\section{RESULTS}

\section{Spectra of whole cell-free supernatants}

CO-binding to a reduced cytochrome causes, among other effects, a broadening of the $\alpha$-band. Thus in difference spectra (reduced plus $\mathrm{CO}$ minus reduced) a trough is observed at the original $\alpha$-band position. If this is close to the $\alpha$-band maximum for a $b$-type cytochrome (557 to $561 \mathrm{~nm}$ ) the cytochrome is denoted cytochrome $o$. A trough at a lower wavelength, $550-554 \mathrm{~nm}$, is expected for a CO-binding cytochrome $c$, denoted cytochrome $c_{\mathrm{CO}}$. Figure 1 shows the CObinding spectrum of an unfractionated cell-free supernatant. The spectral features are essentially the same as those reported by Rees \& Nason (1965). Notably, the $\alpha$-band trough is at $550.5 \mathrm{~nm}$ with no sign of any shoulder at longer wavelengths. In 1965, no CO-binding cytochrome $c$ had been described, and consequently Rees $\&$ Nason attributed this feature to a cytochrome $o$. Subsequently, similar cytochromes were observed in many other bacteria 
Table 1. Summary of purification scheme

\section{Fraction}

Whole extract

$75-90 \%\left(\mathrm{NH}_{4}\right)_{2} \mathrm{SO}_{4}$

fraction

S-200 column (pooled

peak fractions)

DE-52 column

(pooled peak fractions)

DE-52 column

(pooled peak fractions)

$\begin{array}{cccc}\begin{array}{c}\text { Protein } \\ \left(\mathrm{mg} \mathrm{ml}^{-1}\right)\end{array} & \begin{array}{c}\text { Volume } \\ (\mathrm{ml})\end{array} & \begin{array}{c}\text { Specific activity } \\ \left.\text { (arbitrary oxidase units } \mathrm{mg}^{-1}\right)\end{array} & \begin{array}{c}\text { Yield } \\ (\%)\end{array} \\ 13 & 78 & 16 \cdot 5 & 100 \\ 11.5 & 5 \cdot 2 & 255 & 91 \cdot 1 \\ 0.48 & 20 & 1740 & 99 \cdot 8 \\ 0.29 & 26.4 & 1860 & 85 \cdot 1 \\ 0.034 & 39.6 & 4630 & 37.3\end{array}$

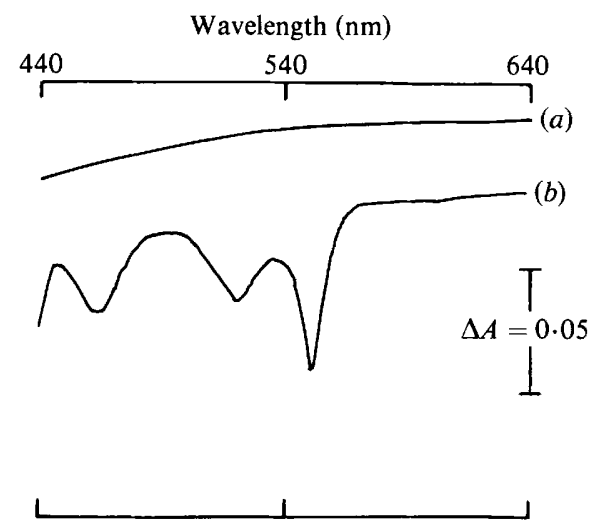

Fig. 1. CO-difference spectrum of whole cell-free supernatant. The supernatant from the initial centrifugation step following freeze-thaw treatment was diluted 20 -fold in $50 \mathrm{mM}$-HEPES/ $\mathrm{NaOH}+$ $100 \mathrm{~mm}-\mathrm{NaCl}, \mathrm{pH} 7 \cdot 7$, and reduced by addition of a few crystals of sodium dithionite. Equal volumes of the reduced preparation were then dispensed into two stoppered glass cuvettes of $1 \mathrm{~cm}$ light path, and the baseline spectrum (a) recorded on a Pye-Unicam SP8-200 spectrophotometer. The sample cuvette was then bubbled with $\mathrm{CO}$ for $2 \mathrm{~min}$, stoppered, and the resulting difference spectrum $(b)$ recorded immediately.

(Weston \& Knowles, 1973). We have found evidence for two distinct cytochromes $c_{\mathrm{CO}}$ (D. J. Miller \& P. M. Wood, unpublished results). Rees \& Nason (1965), followed by others (see Introduction), assumed that this cytochrome $o$ was responsible for the cytochrome $c$ oxidase activity. We have found the soluble oxidase to be readily separable from the bulk of the CObinding cytochromes by ammonium sulphate fractionation; the fraction precipitating between 50 and $75 \%$ saturation contained the cytochrome $c_{\mathrm{CO}}$, while the soluble oxidase was recovered in the fraction precipitating between 75 and $90 \%$ saturation. Such fractionation revealed a further minor component giving a trough in CO-difference spectra at $557 \mathrm{~nm}$. This was identified as peroxidase, a protein purified from $N$. europaea and characterized by Anderson et al. (1968).

Spectra of purified soluble cytochrome oxidase and molecular weight determinations

Highly purified preparations of the soluble cytochrome oxidase showed only a single peak (at $280 \mathrm{~nm}$ ) between 250 and $900 \mathrm{~nm}$. However, the concentrations of protein used were low $\left(50 \mu \mathrm{g} \mathrm{ml}^{-1}\right)$ so that minor spectral features may have been overlooked. The native molecular weight of the protein, determined by gel-filtration on Sephacryl S-200, was approximately 120000. The following proteins were used to calibrate the column: N. europaea hydroxylamine oxidase (mol. wt 200000), bovine serum albumin (mol. wt 68000), ovalbumin (mol. wt 45000), trypsinogen (mol. wt 24400) and horse heart cytochrome $c$ (mol. wt 11700). 
Table 2. Comparison of inhibitor profiles for the soluble cytochrome oxidase and nitrite reductase

$\mathrm{O}_{2}$ uptake assays with $p$-phenylene diamine as electron acceptor were conducted as described in Methods using approx. $5 \mu \mathrm{g}$ purified oxidase preparation in a total assay volume of $1.5 \mathrm{ml}$. The rate of $\mathrm{O}_{2}$ uptake in the absence of inhibitor was determined over $5 \mathrm{~min}$, then the inhibitor was added as 5 to $10 \mu \mathrm{l}$ of neutralized solution and the rate measured over a further 5-10 $\mathrm{min}$. The effect of DEDTC on oxidase activity was determined in $0.1 \mathrm{M}$-potassium phosphate buffer, $\mathrm{pH} 6.0$, under the same conditions.

\begin{tabular}{|c|c|c|c|c|c|}
\hline \multirow[b]{2}{*}{ Inhibitor } & \multicolumn{2}{|c|}{$\mathrm{O}_{2}$ uptake } & \multicolumn{2}{|c|}{$\mathrm{NO}_{2}{ }^{-}$removal } & \multirow[b]{2}{*}{ Reference } \\
\hline & $\begin{array}{l}\text { Inhibitor } \\
\text { concn } \\
(\mathrm{mm})\end{array}$ & $\begin{array}{c}\text { Inhibition } \\
(\%)\end{array}$ & $\begin{array}{l}\text { Inhibitor } \\
\text { concn } \\
(\mathrm{mm})\end{array}$ & $\begin{array}{c}\text { Inhibition } \\
(\%)\end{array}$ & \\
\hline $\mathrm{KCN}$ & 1 & 62 & $0 \cdot 5$ & 77 & Hooper (1968) \\
\hline & 2 & 89 & $0 \cdot 1$ & 0 & Ritchie \& Nicholas (1974) \\
\hline $\mathrm{NaN}_{3}$ & $\begin{array}{l}0 \cdot 5 \\
1\end{array}$ & $\begin{array}{l}34 \\
51\end{array}$ & $1 \cdot 5$ & 57 & Hooper (1968) \\
\hline DEDTC & $0 \cdot 1$ & 0 & $\begin{array}{c}6 \times 10^{-3} \\
2 \times 10^{-3} \\
0 \cdot 1\end{array}$ & $\begin{array}{r}100 \\
55 \\
100\end{array}$ & $\begin{array}{l}\text { Hooper (1968) } \\
\text { Hooper (1968) } \\
\text { Present study }\end{array}$ \\
\hline $\begin{array}{l}\text { EDTA } \\
\mathrm{NaNO}_{2}\end{array}$ & $\begin{array}{r}5 \\
10\end{array}$ & $\begin{array}{l}0 \\
0\end{array}$ & & & \\
\hline
\end{tabular}

The sub-unit molecular weight, as determined by SDS-PAGE on $13.5 \%$ slab gels using a Laemmli-type gel system (Laemmli, 1970), was approximately 35000. Protein staining of SDSslab gels showed that the major component accounted for at least $90 \%$ of the total protein present, though a trace of protein running at about 28000 mol. wt (possibly a proteolytic fragment) was also present in these highly purified preparations. The soluble cytochrome oxidase therefore probably consists of three or (more likely) four identical sub-units.

\section{Copper content}

The highly purified soluble cytochrome oxidase was devoid of haem but contained $3.72 \pm$ $0.2 \mathrm{~mol}$ of copper per mol of protein (mean of four determinations) assuming a molecular weight of 120000 . The protein therefore probably bears one copper atom per sub-unit.

\section{Nitrite reductase activity of cytochrome oxidase preparations}

The soluble cytochrome oxidase activity always co-purified with nitrite reductase activity, the final oxidase preparations always giving specific activities of 2 to $10 \mu \mathrm{mol} \mathrm{min}-1 \mathrm{mg}^{-1}$, at least an order of magnitude higher than those of the most highly purified preparations of Ritchie \& Nicholas $(1972,1974)$. The elution behaviour from ion-exchange columns and mol. wt on gel filtration also agree well with those reported for nitrite reductase activity by earlier authors.

\section{Electron donor specificity and inhibition profile}

As described by previous authors (Hooper et al., 1972) the soluble cytochrome oxidase activity has a broad specificity, accepting electrons from DCPIP, DAD, ascorbate and $p$-phenylene diamine in addition to cytochrome $c-552$ from $N$. europaea and horse heart cytochrome $c$. The $K_{\mathrm{m}}$ for horse heart cytochrome $c$ was very high $(200 \mu \mathrm{M})$, but the corresponding figure for cytochrome $c-552$ was $10 \mu \mathrm{M}$.

Table 2 summarizes results of inhibition experiments with soluble cytochrome oxidase preparations and compares these with published and present data for the nitrite reductase activity. The only major difference in the inhibition profiles is in the effect of DEDTC, which did not affect oxidase activity, but which inhibited nitrite reductase activity when present at very low levels. 
DISCUSSION

The soluble cytochrome oxidase, previously described as cytochrome $o$, is a copper protein devoid of haem. It has a molecular weight of 120000 and probably consists of four identical subunits each having a single copper atom. It is almost certainly also responsible for the nitrite reductase activity of $N$. europaea. Copper-type nitrite reductases have been reported for Alcaligenes sp. (formerly called $P$. denitrificans), Alcaligenes faecalis, Achromobacter cycloclastes and Rhodopseudomonas sphaeroides $\mathrm{f}$. denitrificans (Iwasaki \& Matsubara, 1972; Iwasaki et al., 1975; Sawada et al., 1978; Kakutani et al., 1981). The three cases tested also possess cytochrome oxidase activity, and this is true also for the cytochrome $c d_{1}$ type of nitrite reductase (Yamanaka \& Okunuki, 1963; Miyata \& Mori, 1969; Iwasaki et al., 1975; Sawada et al., 1978). This duality may reflect similarities between nitrite reduction to $\mathrm{N}_{2} \mathrm{O}$ and $\mathrm{O}_{2}$ reduction to $\mathrm{H}_{2} \mathrm{O}$, both being four electron processes with $E_{\mathrm{m}, 7}$ close to $+800 \mathrm{mV}$. The copper-type nitrite reductases vary considerably in molecular weight and apparent subunit structure; that of Alcaligenes faecalis is closest to the figures reported here, having a tetrameric structure with one copper atom per subunit molecular weight of 30000 (Kakutani et al., 1981). The inhibition profiles of coppercontaining nitrite reductases have been reported (Iwasaki \& Matsubara, 1972; Iwasaki et al., 1963; Miyata \& Mori, 1968; Kakutani et al., 1981; Sawada et al., 1978), but no one has mentioned the effect of inhibitors on oxidase activity. Generally this class of protein is strongly inhibited by $\mathrm{KCN}$ or DEDTC $(0 \cdot 1$ to $1.0 \mathrm{~mm})$ and relatively insensitive to azide at these levels. By contrast, the $N$. europaea protein is sensitive to $1 \mathrm{~mm}$-azide, while the absence of inhibition of the oxidase activity by $0.1 \mathrm{~mm}$-DEDTC is also noteworthy. Hooper et al. (1977) found that addition of DEDTC to aerobic assays for hydroxylamine oxidase activity led to its oxidation, so it cannot be assumed to act solely as a metal-chelating agent.

Why should $N$. europaea contain a soluble cytochrome oxidase/nitrite reductase? The dissimilatory nitrite reductase is normally associated with facultative anaerobes, for which it allows nitrite to be used as an alternative electron acceptor when oxygen is depleted. Yet $N$. europaea is an obligate aerobe, and requires oxygen in particular for the monooxygenase reaction that converts ammonia to hydroxylamine. The use of this protein as an alternative to the membrane-bound cytochrome $a$ seems wasteful. Membrane cytochrome oxidases can take the protons required for $\mathrm{O}_{2}$ reduction from the cytoplasm, thereby contributing to the protonmotive force. By contrast, the soluble oxidases/nitrite reductases are periplasmic for all cases where this has been determined (Wood, 1978; Sawada \& Satoh, 1980), so the protons would have to come from outside. Measurement of relative $K_{\mathrm{m}}$ values for $\mathrm{O}_{2}$ would help establish whether the oxidase activity has any physiological significance. With the nitrite reductase activity the position is rather different. It is well known that nitrifiers such as $N$. europaea produce a small amount of $\mathrm{N}_{2} \mathrm{O}$, with the yield rising markedly as the oxygen tension falls (Lipschultz et al., 1981). Nitrite will normally be available to the cells, and nitrite reductase activity could be useful by enabling a sparing of oxygen when only limited amounts are available.

This research was supported by a grant from the Science and Engineering Research Council. The technical assistance of Dr S. Hopkin is gratefully acknowledged.

\section{REFERENCES}

Anderson, J. R., Strumeyer, D. H. \& Pramer, D. (1968). Purification and properties of peroxidase from Nitrosomonas europaea. Journal of Bacteriology 96, 93-97.

ERICKSON, R. H. \& HoOPER, A. B. (1968). A soluble hydroquinone oxidase from Nitrosomonas europaea. Bacteriological Proceedings 68, 140.

ERICKSON, R. H. \& HoOPER, A. B. (1972). Preliminary characterization of a variant $\mathrm{CO}$-binding heme protein from Nitrosomonas. Biochimica et biophysica acta 75, 231-244.
Erickson, R. H., HoOper, A. B. \& TERry, K. R. (1972). Solubilization and purification of cytochrome $a_{1}$ from Nitrosomonas. Biochimica et biophysica acta 283, 155-166.

HOOPER, A. B. (1968). A nitrite reducing enzyme from Nitrosomonas europaea. Preliminary characterization with hydroxylamine as electron donor. Biochimica et biophysica acta 162, 49-65.

HoOper, A. B., ERICKSON, R. H. \& TERRY, K. R. (1972). Electron transport systems in Nitrosomonas: 
isolation of a membrane-envelope fraction. Journal of Bacteriology 110, 430-438.

Hooper, A. B., Terry, K. R. \& Maxwell, P. C. (1977). Hydroxylamine oxidoreductase of Nitrosomonas: oxidation of diethyldithiocarbamate concomitant with stimulation of nitrite synthesis. Biochimica et biophysica acta 462, 141-152.

INGLEDEW, W. J. (1978). Cytochrome- $a_{1}$ as an oxidase? In Functions of Alternative Terminal Oxidases (Proceedings of the 11th FEBS Meeting), pp. 79-87. Edited by H. Degn, D. Lloyd \& G. C. Hill. Oxford: Pergamon Press.

IWASAKI, H. \& Matsubara, T. (1972). A nitrite reductase from Achromobacter cycloclastes. Journal of Biochemistry 71, 645-652.

IWASAKI, H., NoJi, S. \& Shidara, S. (1975). Achromobacter cycloclastes nitrite reductase. The function of copper, amino acid composition and ESR spectra. Journal of Biochemistry 78, 355-361.

Iwasaki, H., Shidara, S., Suzuki, H. \& Mori, T. (1963). Studies on denitrification. VII. Further purification and properties of denitrifying enzyme. Journal of Biochemistry 53, 299-303.

Kakutani, T., Watanabe, H., Arima, K. \& Beppu, T. (1981). Purification and properties of a coppercontaining nitrite reductase from a denitrifying bacterium, Alcaligenes faecalis strain S-6. Journal of Biochemistry 89, 453-461.

LAEMmLI, U. K. (1970). Cleavage of structural proteins during the assembly of the head of bacteriophage T4. Nature, London 227, 680-685.

LipsChultz, F., Zafiriou, O. C., Wofsy, S. C., McElroy, M. B., Valois, F. W. \& Watson, S. W. (1981). Production of $\mathrm{NO}$ and $\mathrm{N}_{2} \mathrm{O}$ by soil nitrifying bacteria. Nature, London 294, 641-643.

Mejbaum-Katzenellenbogen, W. (1955). A new turbidometric micromethod for protein analysis. Bulletin de l'Academie polonaise des sciences, Classe II 3, 171-173.

Miller, D. J. \& Wood, P. M. (1982). Characterization of the c-type cytochromes of Nitrosomonas europaea with the aid of fluorescent gels. Biochemical Journal 207, 511-517

Miyata, M. \& Mori, T. (1968). Studies on denitrification. VIII. Production of nitric oxide by denitrifying reaction in the presence of tetramethyl-p-phenylenediamine. Journal of Biochemistry 64, 849-861.

Miyata, M. \& MoRI, T. (1969). Studies on denitrification. $X$. The denitrifying enzyme as a nitrite reductase and the electron donating system for denitrification. Journal of Biochemistry 66, 463-471.

REES, M. K. (1968). Studies of the hydroxylamine metabolism of Nitrosomonas. I. Purification of hydroxylamine oxidase. Biochemistry 7, 353-365.

ReEs, M. K. \& Nason, A. (1965). A P-450-like cytochrome and a soluble terminal oxidase identified as cytochrome-o from Nitrosomonas europaea. Biochemical and Biophysical Research Communications 21, 248-256.

Ritchie, G. A. F. \& Nicholas, D. J. D. (1972). Identification of the sources of nitrous oxide produced by oxidative and reductive processes in Nitrosomonas europaea. Biochemical Journal 126, 1181-1191.

Ritchie, G. A. F. \& Nicholas, D. J. D. (1974). The partial characterization of purified nitrite reductase and hydroxylamine oxidase from Nitrosomonas europaea. Biochemical Journal 138, 471-480.

Sawada, E. \& Satoh, T. (1980). Periplasmic location of dissimilatory nitrate and nitrite reductase in a denitrifying phototrophic bacterium Rhodopseudomonas sphaeroides forma sp. denitrificans. Plant and Cell Physiology 21, 205-210.

Sawada, E., Satoh, T. \& Kitamura, H. (1978). Purification and properties of a dissimilatory nitrite reductase of a denitrifying phototrophic bacterium. Plant and Cell Physiology 19, 1339-1351.

WARBURG, O. \& CHRISTIAN, W. (1941). Isolierung und Kristallisation des gärungsferments Enolase. Biochemische Zeitschrift 310, 384-421.

Weston, J. A. \& Knowles, C. J. (1973). A soluble CObinding $c$-type cytochrome from Beneckea natriegens. Biochimica et biophysica acta 305, 11-18.

Wood, P. M. (1978). Periplasmic location of the terminal reductase in nitrite respiration. FEBS Letters 92, 214-218.

Yamanaka, T. \& OKunuki, K. (1963). Crystalline Pseudomonas cytochrome oxidase. I. Enzymic properties with special reference to the biological specificity. Biochimica et biophysica acta 67, 379--393. 